\title{
PEMBUATAN AKTA PERDAMAIAN DALAM PENYELESAIAN SENGKETA TANAH ULAYAT MELALUI NOTARIS DI KABUPATEN AGAM
}

\section{TESIS}

Diajukan Untuk Memenuhi Sebagian Persyaratan Memperoleh Gelar Magister Kenotaritan Pada Program Magister Fakultas Hukum Universitas Andalas

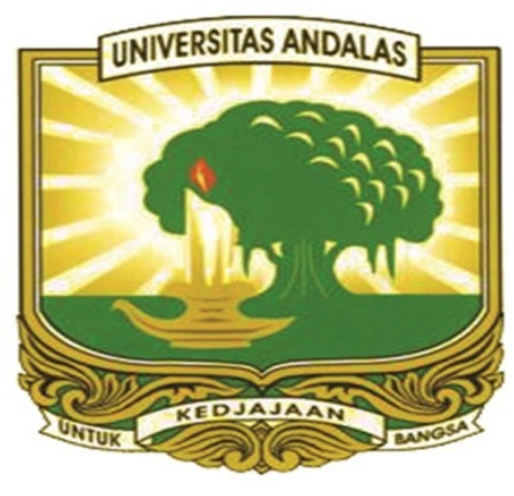

MUHAMAD RASYAD

1620122011

Pembimbing I

Dr. H. Kurnia Warman, SH, M.Hum NIP. 197106301998021002
Pembimbing II

Hj. Sri Arnetti, SH, MH.

NIP.196212051987022001

\section{PRPGRAM MAGISTER KENOTARIATAN \\ FAKULTAS HUKUM \\ UNIVERSITAS ANDALAS PADANG \\ 2018}




\title{
ABSTRAK \\ PEMBUATAN AKTA PERDAMAIAN DALAM PENYELESAIAN SENGKETA TANAH ULAYAT MELALUI NOTARIS DI KABUPATEN AGAM \\ Muhamad Rasyad. 1620122011. Program Magister Kenotariatan Fakultas Hukum Universitas Andalas. Halaman 94. Tahun 2018
}

\begin{abstract}
Hak ulayat merupakan hak tertinggi atas tanah yang dimiliki oleh sesuatu persekutuan hukum (desa, suku) untuk menjamin ketertiban, pemanfaatan/pendayagunaan tanah. Hak ulayat adalah hak yang dimiliki oleh suatu persekutuan hukum (desa, suku), dimana para warga masyarakat (persekutuan hukum) tersebut mempunyai hak untuk menguasai tanah, yang pelaksanaannya diatur oleh ketua persekutuan (kepala suku/kepala desa yang bersangkutan)". Hal lain yang diatur dalam PMNA/Ka.BPN No. 5 Tahun 1999 antara lain Pasal 2 ayat (1) mengatur tentang pelaksanaan hak ulayat sepanjang pada kenyataannya masih ada dilakukan oleh masyarakat hukum adat menurut ketentuan hukum adat setempat. Namun dalam Pasal 3 terdapat pengecualiannya yaitu pelaksanaan hak ulayat tersebut tidak dapat dilakukan lagi terhadap bidangbidang tanah yang pada saat ditetapkannya. Berdasarkan hal tersebut, maka penulis merumuskan permasalahan sebagai berikut 1. Apa yang menjadi faktor penyebab timbulnya sengketa tanah ulayat melalui notaris di kabupaten Agam? 2. Bagaimana penyelesaian sengketa tanah ulayat melalui notaris di kabupaten Agam? 3. Bagaimana akibat hukum akta perdamaian terhadap sengketa tanah ulayat di Kabupaten Agam?.

Berdasarkan hasil metode penelitian dapat disimpulkan faktor penyebab terjadinya sengketa tanah ulayat pada keluarga almarhum Nurlela yang bersuku tanjung diJorong Durian Kapeh nagari Tiku Utara kabupaten Agam yaitu faktor penguasaan tanah yang dilakukan oleh anak laki-laki tanpa bermusyawarah dengan saudara-saudaranya. 2. Cara yang di tempuh oleh suku tanjung dalam penyelesaian sengketa tanah ulayatnya adalah melalui non litigasi dengan cara musyawarah dan mufakat dalam keluarga. 3. Proses penyelesaian sengketa tanah suku tanjung di Jorong Durian Kapeh nagari Tiku Utara dengan cara sebagai berikut: a. Mengumpulkan keseluruh pihak-pihak yang bersengketa dilaksanakan oleh mamak kepala suku tanjuang Jorong Durian Kapeh nagari Tiku Utara. b. Mendengarkan pendapat masing-masing pihak yang bersengketa. c. Akibat hukum akta bawah tangan tergantung pada tanda tangan para pihak, apabila tanda tangan disangkal atau diingkari, maka kekuatan daya formil dan materiilnya bisa jadi lenyap., namun demikian tujuan pengingkaran tanda tangan mempunyai makna yang sangat positif, yaitu untuk menghindari terjadinya pemaksaan tanda tangan sewenang-wenang.
\end{abstract}

Kata kunci: Akta Perdamaian, Penyelesaian Sengketa, Tanah Ulayat dan Notaris 


\title{
ABSTRACT \\ THE DEVELOPMENT OF PEACE DEED IN THE SETTLEMENT \\ OF ULAYAT LAND DISPUTES THROUGH A NOTARY \\ IN KABUPATEN AGAM
}

\author{
Muhamad Rasyad.1620212011 \\ Program Magister of Notary of Law Faculty of Universitas Andalas. Page 94. \\ Year 2018
}

Hak Ulayat is the right onto land owned legally by a certain alliance (county, tribe) to guarantee the order and the utilization of the land. It is the highest right owned by the alliance (county, tribe) in which the citizens (law alliance) have the right to control the land; and its implementation is governed by the leader of the alliance, including Ithel leader of the tribe and the head of the village or county. Other regulation on the land is ruled in PMNA/Ka.BPN No.5, year 1999, such as Article 2 section (1) regulates the implementation of Ulayat Rights insofar as they are still conducted by the customary law community based on its local customary law. However, in Article 3 there is an exception that the implementation of Ulayat Right cannot be carried out anymore to the areas of land at the time of its enactment. For these reasons, the writer formulates the following problems: 1 . What are the factors causing the disputes of ulayat land through a notary in Kabupaten Agam? 2. How is the settlement of ulayat land disputes through a notary in Kabupaten Agam? 3. How is the impact of law of peace deed over the land disputes in Kabupaten Agam?

Based on the result of the research, it can be concluded that the factors which cause ulayat land disputes in the family of deceased Nurlela whose tribe is Tanjung in Jorong Durian Kapeh Nagari Tiku Utara Kabupaten Agam are (1) The land tenure is controlled by the sons without deliberation with their siblings. (2) The way taken by Tanjung tribe in the settlement of ulayat land disputes is through non-litigation or no deliberation and consensus in the family. (3) The process of settlement of land dispute in Tanjung tribe in Jorong Durian Kapeh Nagari Tiku Utara is as follow: a. Gathering all the parties to the disputes which is conducted by Mamak, Tanjung tribal leader in Jorong Durian Kapeh Nagari Tiku Utara; $b$. Considering the opinions of each party to the disputes; $c$. The impact of law under the hands depends on the signatures of all parties; if the signatures are denial, the power of its formal and material becomes vanish. However, the purpose of the denial of signatures has positive meaning, i.e. to avoid the unlawful coercion of signatures.

Keywords: Deed of Peace, Dispute, Notary, Settlement, Ulayat Right. 